\title{
The hydrocarbon prospectivity of the Mesoproterozoic-Paleozoic intracratonic Voltaian Basin, West African Craton, Ghana
}

\author{
Mahamuda Abu ${ }^{1,2}$ (i) $\cdot$ Mutiu Adesina Adeleye $\mathrm{e}^{2,3} \cdot$ Olugbenga Ajayi Ehinola ${ }^{2,3} \cdot$ Daniel Kwadwo Asiedu $^{4}$
}

Received: 21 April 2020 / Accepted: 26 October 2020 / Published online: 9 November 2020

(c) The Author(s) 2020

\begin{abstract}
Neoproterozoic sedimentary basins are increasingly gaining hydrocarbon exploration attention globally following results of significant discoveries in these basins as a result of long, consistent and focused research and exploration efforts. The hydrocarbon prospectivity of the unexplored Mesoproterozoic-Early Paleozoic Voltaian basin is reviewed relative to global Neoproterozoic basins. Like the Voltaian basin of Ghana, global Neoproterozoic basins have experienced similar geological event of glaciation with accompanying deposition of marginal-shallow marine carbonates and associated siliciclastic argillaceous sediments. These carbonates and argillaceous sediments coupled with deep anoxic depositional environments, favored the preservation of organic matter in these sediments and carbonates globally making them source rocks and in some cases the reservoir rocks as well, to hydrocarbon occurrence. The hydrocarbon prospectivity of the Voltaian is highly probable with Neoproterozoic basins of similar geologic analogies, Amadeus basin, Illizi basin, the Tindouf and Taoudeni basins of the WAC, having proven and active petroleum systems with some listed as world class oil/gas producing basins together with other Neoproterozoic basins like South Salt Oman basin, Barnett shales and giant gas reserves of southwestern Sichuan basin of China.
\end{abstract}

Keywords Hydrocarbon $\cdot$ Neoproterozoic-Paleozoic $\cdot$ Prospectivity $\cdot$ Voltaian $\cdot$ Ghana $\cdot$ West african craton

\section{Introduction}

Globally, the interest in Neoproterozoic stratigraphically deeply buried petroleum systems, which is otherwise known as unconventional hydrocarbon system, is increasing (Craig et al. 2009, 2010, 2012). This is as a result of their large recoverable potential, the tight shale and sands

Mahamuda Abu

mahamudaabu@gmail.com

1 Department of Earth Science, Faculty of Earth and Environmental Sciences, CKT - University of Technology and Applied Sciences, P. O. Box, 24, Navrongo, Ghana

2 Department of Geology, Pan African University Institute of Life and Earth Sciences, University of Ibadan, Ibadan, Nigeria

3 Department of Geology, University of Ibadan, Ibadan, Nigeria

4 Department of Earth Science, School of Physical and Mathematical Sciences, College of Basic and Applied Science, University of Ghana, Legon, Ghana gas as well as coal bed methane storage properties (Jarvie 2012). According Wang et al. (2016), exploitation of unconventional oil and gas has considerably increased, such that in 2015, annual global unconventional oil accounted for $9 \%$ and $27 \%$ for unconventional gas globally relative to $4 \%$ and $12 \%$, respectively, in 2012 (Sieminski 2016).

Generally, the petroleum exploration in this global Precambrian terrain is not extensive with exploration in this geological terrain in Africa still at an infant stage. However, following a continuous, systematic and focus exploration works on the Murzuq basin, Lybia, there has been a world class giant oil discovery in the El Feel Field, thus the "Elephant field" (Craig et al. 2009). This discovery indicated that there is a potential and an unexplored petroleum resource in this geological terrain. Craig et al. (2009) envisaged that if consistent, systematically continuous and active research work could be carried out in the Northwest Africa Neoproterozoic basins, the region could prove to be the new challenging frontier when it comes to unconventional hydrocarbon prospecting.

The Large central Taoudeni basin, the smaller northern Tindouf and southeastern Voltaian basins of the West

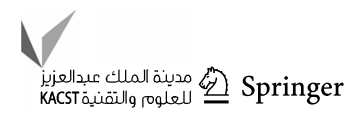


African Craton (WAC), following a long basement peneplanation during the mid-Proterozoic (1.9-1.0 Ga) (Goodwin 1996), resulted in the down-warping of the larger central part, northern and southeastern parts giving rise to the accumulation of sediments defining the Taoudeni, Tindouf and Voltaian basins, respectively. Sedimentation began in the larger Taoudeni and the smaller Voltaian basins simultaneously with sandstones, which is referred to as the Supergroup 1 according to Affaton et al. (1980) and Kwahu/Bombouaka
Group (Affaton et al. 1980; Anani 1999; Carney et al. 2010) or Kwahu/Gambaga (Anani et al. 2017) in Ghana, with the accumulation of sediments starting in about $1034 \mathrm{Ma}$. The Supergroup 1 as referred to in the Taoudeni basin is laterally equivalent to the Kwahu/Gambaga Group (Anani et al. 2017) of the Voltaian basin (Fig. 1; Table 1). The deposition of the Supergroup 1 and the Kwahu/Gambaga Group in Taoudeni and Voltaian basins, respectively, ended at the beginning of the tillites at about 690-605 Ma (Goodwin

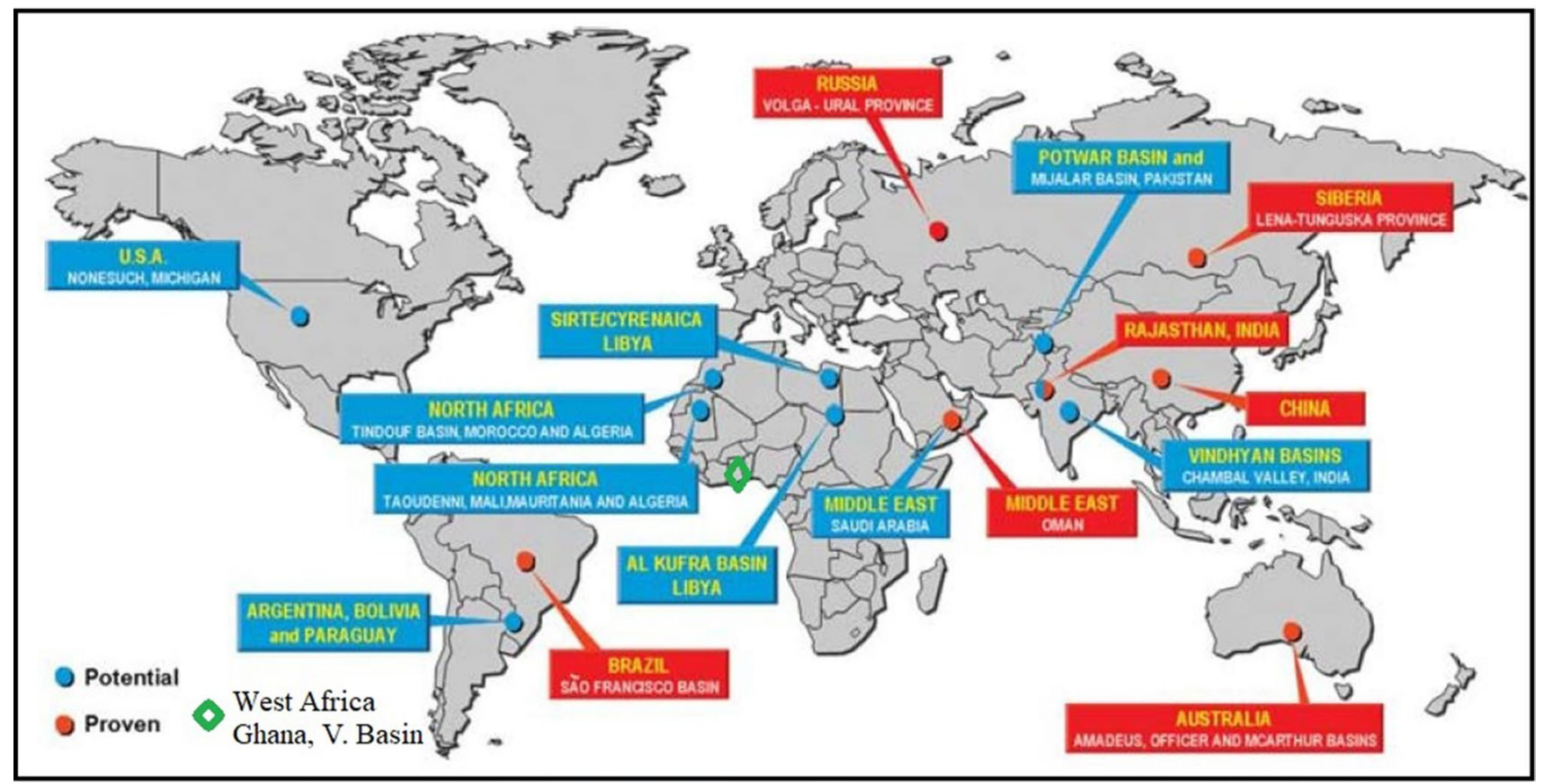

Fig. 1 Distribution of global Neoproterozoic sedimentary basins with proven and potential hydrocarbons with unexplored Voltaian basin of Ghana in perspective. Modified after Craig et al. (2009)

Table 1 The Geological time and the lithostratigraphic sequence of the Voltaian basin (Grant 1969; Bozhko et al. 1971; Clauer 1976; Saunders 1970; Goodwin 1996; Barfod et al. 2004; Nédélec et al. 2007; Kalsbeek et al. 2008; Carney et al. 2008; Akah 2008)

\begin{tabular}{|c|c|c|c|c|c|c|}
\hline \multicolumn{2}{|l|}{ Geological time } & \multirow{2}{*}{$\frac{\text { Group }}{\text { Tamale/Obosum }}$} & \multirow{2}{*}{$\begin{array}{l}\text { Fm. } \\
\text { Tamale/Obosum }\end{array}$} & \multirow{2}{*}{$\begin{array}{l}\text { Lithology } \\
\begin{array}{l}\text { Sandstones, congl. and } \\
\text { argillaceous mats }\end{array}\end{array}$} & \multicolumn{2}{|c|}{ Thickness } \\
\hline Paleozoic (450-320 Ma) & Ordovician-Carboniferous & & & & $\sim 400 \mathrm{~m}$ & $\sim 5-7 \mathrm{Km}$ \\
\hline \multicolumn{7}{|c|}{ Unconformity: Erosion, Nondeposition or Downwarping } \\
\hline \multirow[t]{2}{*}{$\begin{array}{l}\text { Neoproter-zoic (675-600 } \\
\text { Ma) }\end{array}$} & Ediacaran (Marinoan) & Oti/Pendjari & Pendjari & $\begin{array}{l}\text { Argillaceous mats. and } \\
\text { Minor wackes }\end{array}$ & $\sim 2800 \mathrm{~m}$ & \\
\hline & Late Cryogenian (Sturtian) & & Kodjari & $\begin{array}{l}\text { Carbonates, chert and } \\
\text { tillites }\end{array}$ & $\sim 110 \mathrm{~m}$ & \\
\hline \multicolumn{7}{|c|}{ Unconformity: Erosion or Nondeposition ( $\sim 350 \mathrm{Ma})$} \\
\hline \multirow[t]{3}{*}{$\begin{array}{l}\text { Late Mesproter-zoic } \\
\qquad(1100 / 1034 / 993 \mathrm{Ma})\end{array}$} & & Kwahu/Panabako & Poubogou & $\begin{array}{l}\text { Sandstones (Qztic. and } \\
\text { Feldspathic) }\end{array}$ & $\sim 600 \mathrm{~m}$ & \\
\hline & & Bombouaka & Tossiegou & Sandy Shales & $\sim 260 \mathrm{~m}$ & \\
\hline & & & & $\begin{array}{l}\text { Sandstones and Minor } \\
\text { Mudstones }\end{array}$ & $\sim 500 \mathrm{~m}$ & \\
\hline
\end{tabular}


1996) which is separated from the underlying sandstones of Supergroup 1 with an unconformity. The Supergroup 2 in the Taoudeni basin, thus the Oti/Pendjari Group in the Ghanaian nomenclature, begins with glaciation (Sturtian and Marinoan), characterized by tillites, cherty-like beds (silixites) and barite bearing carbonates which are referred to as the 'Triads' in the Taoudeni basin and defines the Kodjari Formation (Table 1) in the Voltaian basin of Ghana (Affaton et al. 1980).

The Voltaian basin of Ghana is the smaller equivalence of the larger central Taoudeni basin with similar geological analogies (Affaton et al. 1980; Apesigah 2008). The review seeks to highlight and to justify from similar Neoproterozoic sedimentary basins exploration successes and with emphasis on similar geological analogies of the WAC. The Voltaian basin although there have not been any exploration efforts made on the basin up to date following the poor petroleum resource indications from the Premuasi-1 well drilled in 1977, the basin if similar efforts in terms of money, time, dedication and focus research work can be made similar to other current prolific petroleum producing, proven and active global Neoproterozoic basins (Fig. 1), discoveries can be made from the basin significant enough to add to the hydrocarbon reserves of the country and to global Neoproterozoic reserves.

\section{Neoproterozoic petroleum systems}

\section{Global Neoproterozoic petroleum occurrence}

Neoproterozoic epoch marks a period in Earths' history where globally, glaciation affects life evolution on Earth (Hoffman and Schrag 2002; Ghori et al. 2009). This glaciation which was episodic was characterized by long periods of oxygen poor oceanic environments with significant accumulation of organic rich sediments in fluvial-marine environments following transgressive systems, recording total organic carbon (TOC) content as high as 30\% according Mckirdy and Imbus (1992). This glacial event globally is associated with deposition of argillaceous detrital material of fluvial environments over carbonates and dolomitic carbonate rocks during this period (Amthor et al. 2005; Nédélec et al. 2007; Grosjean et al. 2009). Largely, the source rock(s) to the global Neoproterozoic oil and gas fields currently producing prolifically and under serious consideration for development to add to the global Neoproterozoic unconventional reserves, are sourced from dolomitic limestones/ carbonates and their associated shales (Dardour et al. 2004). For instance in southwestern China the prolific Weiyuan gas field of the Sichuan basin is sourced and stored in the same Neoproterozoic succession of dolomitic carbonates and microbial dolomites, respectively, suggesting a single source hydrocarbon system, hence a probable unconventional petroleum system (Hao and Liu 1989; Ma et al. 2008; Ghori et al. 2009). The petroleum field in southwestern Chinas' Sichuan basin is about 300 gas pool discoveries were made in the basin after 50 long years of continuously focused and systematic research and exploration on the basins' hydrocarbon prospects (Wang et al. 2005; Zhu et al. 2006; Ma et al. 2008). Notwithstanding the difficulty and cost intensiveness of hydrocarbon exploration in Neoproterozoic basins, continuous exploration with the hope of adding to the hydrocarbon reserves within the basin yielded positive results (Zhang et al. 2006) with the discovery of an additional giant carbonates hosted Puguang gas field in the northeastern parts of the Sichuan basin.

The Neoproterozoic Baykit High region of eastern Siberia, with Ediacaran faunal association of acritarchs and metazoans, has proven to be a suitable habitat of hydrocarbons (Ulmishek 2001; Yin et al. 2004; Kelly et al. 2011). Like other unconventional petroleum systems, the Baykit High petroleum system is believed to a single sourced petroleum system (Kelly et al. 2011), although the source of the petroleum occurrence has not been located within the Baykit High, adjacent thick OM rich shales of the Tungusik series of about $1050 \mathrm{Ma}$ is suspected to be the source of the Siberian Precambrian petroleum resource. Yenisey Ridge Fold belt (850-820 Ma) to the west of the Baykit High however have $\mathrm{OM}$ rich shales and carbonates and their potential of sourcing the Baykit High session hydrocarbon occurrence cannot be precluded.

The South Oman Salt basin, thus the Huqf Group has its oldest sediments lying unconformably on metamorphose crystalline basement rocks (Mattes and Morris 1990) in association with continental sediments and mixtiles of glacial provenance. The youngest of the Huqf Group, the Ara Formation, is defined by carbonates and siliciclastics of marginal to shallow marine environment. The formation also has a thick salt succession that straddles the boundaries of Cambrian-Precambrian geological times. The situation of the style of hydrocarbons occurrence in the Huqf basin of Oman is not different, in that the oil is sourced from lenses of carbonate rocks and hosted within the carbonates (reservoirs) according Konert et al. (2001). These carbonates as source rocks in Oman have TOC of about $8 \%$ with average hydrogen index (HI) of $600 \mathrm{mg} \mathrm{HC} / \mathrm{TOC}$ (Grosjean et al. 2009). The carbonates in the deeper parts of the basin have records of some of the shelly organic matter of Neoproterozoic geological time deposited in an anoxic environment. This allows the preservation of a prolific organic matter detritus and subsequently the formation of organic matter rich carbonate source rocks in the South Oman Salt basin, which resides in the Ara Formation of the Huqf Group.

Eagle Ford, Barnett and Marcellus of North America have proven reserves sourced from Neoproterozoic deeply 
buried unconventional 'tight' petroleum systems. These to a large extend according Energy Information Administration (2015), Hackley et al. (2016) is responsible for USA being ranked as the leading world producer of oil and gas since 2013. These oil-shales in North America are characterized by solid oily bitumen as the main organic matter (Hackley et al. 2016; Wang et al. 2016).

The Neoproterozoic Damaran succession of Namibia as a result of the northern Namibia rifting event, resulting in the accumulation of about $5 \mathrm{~km}$ thick (Beukes 1986; Bechstadt et al. 2009) Neoproterozoic sediments. The sedimentary succession of the Damara Group defines the northern parts of the Congo Craton. The Otavi Group of dominant shallow marine carbonates rocks of the Damaran succession, unconformably, overlies partly on the Paleoproterozoic crystalline basement rocks and largely on the Cryogenian detritus of the Nosib Group (Laukamp 2006). The Ghaub Formation of Cryogenian age according Hoffman et al. (2004), of the Otavi Group have cap carbonates comprising of limestones and dolomites overlying diamictites and dark dolomitic shales (Bechstadt et al. 2009). The diamictites, cap carbonates succession of the Ghaub Formation of the Otavi Group, correlates with global Cryogenian (Marinoan) glacial period in geological history. The carbonates have significant amount of organic matter (OM) to make them probable source or reservoir rocks like other Neoproterozoic sedimentary successions.

\section{Northwest Africa petroleum prospective}

The North Africa petroleum prospects are made up of basins in Morocco (Anti Atlas), Algeria (subsurface Illizi basin) and Libya (Murzuq and Al-Kufra basins) (Le Heron et al. 2009). The petroleum system of North Africa is broadly Cambrian to Ordovician with some isolated cases of early Silurian to Devonian source rocks observations (Craig et al. 2010). The Ordovician quartzites of the Hamra formation, which are the main reservoir rocks in the Illizi basin of Algeria are separated from the underlying El Gassi Shale which is about $200 \mathrm{~m}$ thick in Tassili N' Ajers areas. The older Cambrian contains the reservoir rocks that are generally with poor reservoir properties due to quartz overgrowth serving as cementing medium that occludes pores, however there is local porosity as a result of kaolinite transformation into dickite (Craig et al. 2010). This poor porosity is largely due to a probable re-burial after the Hercynian tectonic uplift event. The Ordovician El Gassi Shale of Algeria, although with a variable TOC content of less than $1.5 \%$ regionally, has local TOC content of about $8.6 \%$ and is considered (Le Heron et al. 2009; Craig et al. 2010) as the source to the hydrocarbons in Algeria although there is the need for further work. The giant Hassi Messaoud oil Field (HMF) is sourced from both Silurian and Ordovician. Other limited source potential (TOC less than 1\%) has been observed in the Azzel Shales and the conglomeratic shales in the Illizi basin (Bacheller and Peterson 1991). The reservoirs in North Africa are largely and almost of the Upper Ordovician. There contain significant reserves in over 50 oil fields that are distributed across a regional area from the Murzuq basin in SW Libya to the central parts of Algeria and this includes the giant El Feel Field of the Murzuq basin (Hirst et al. 2002; Ghienne 2003; Le Heron et al. 2004; Dardour et al. 2004). The deposition of the reservoir unit/section in these basins is generally associated with glacial events and broadly of shallow marine sediments of continental shelf environments (Le Heron et al. 2009; Le Heron and Dowdeswell 2009). The absence of highly fractured reservoirs in the Hamra reservoir quartzites of the Illizi basin of Algeria and other equivalent reservoir units in North Africa is the main and current progressive exploration challenge in the region.

\section{Petroleum exploration in the Taoudeni basin}

The Taoudeni basin is one of the supercrustals and Intracratonic basins of the WAC occupying most parts of North and West Africa with an estimated total area of about $1,500,000 \mathrm{~km}^{2}$ (Gang 2009). The hydrocarbon prospects in this basin still remain under-explored. However, the drill wells in Mauritania (Abolag-1 well), Yarba-1 well in Mali, Hank-1 and Ouasa-1 wells, with the Abolag-1 (Fig. 1) well reaching a depth of about $600 \mathrm{~m}$ (Craig et al. 2010) has indicated the presence of an active petroleum system in the Taoudeni basin. The hydrocarbons in the Atar Group which is about $1000 \mathrm{~m}$ thick in the Adrar area at the northern margin of the Taoudeni basin (BertrandSarfati and Moussine-Pouchkine 1998) have stromatolitic limestones as the reservoir rocks and sourced from organic rich shales that are deposited in restricted sub basins and sealed by interbedded shales. The Abolag-1 well within the Atar Group of the Taoudeni basin according AlbertVillanueva et al. (2016), has solid hydrocarbons (pyrobitumen) present within dolomitized stromatolitic carbonates, the pyrobitumen formation is associated with a thermal event which peaked locally at $380{ }^{\circ} \mathrm{C}$ and subsequently hydro-fracturing the carbonates (Albert-Villanueva et al. 2016). Gas shows from the Abolag-1 well from the carbonates indicates that these carbonates are potential reservoirs (Albert-Villanueva et al. 2016). The carbonates in the succession, thus in the Abolag-1 well, subsequent dating show they were between 1000 and 800 Ma suggesting they are Tonian in age (Craig et al. 2010), thus Meso-Neoproterozoic. The Atar Group has at its base, organic rich shale with potential source rock characteristics (Craig et al. 2012; Lottaroli et al. 2009). According Lottaroli et al. (2009) and Beghin et al. (2017), the organic species recovered from the Abolag-1 well is composed 
of an assemblage of acritarchs, cyanophyte filaments and amorphous organic matter (AOM) with total organic content (TOC) in the range of 10-20\% within the Atar Group at around Aguelt El Mabha, and hydrogen index (HI) of about $225 \mathrm{mg} / \mathrm{g}$ TOC. The association of significant amount of AOM with the organic matter rich shales is consistent with Neoproterozoic oil-prone shales globally (Lattaroli et al. 2009). Gang (2009) also reported mud rock source rocks in the Abolag-1 well with TOC content of about $2.65 \%$. Dark organic matter bearing stromatolic limestone is recovered in the AZ-1 well also in the northern parts of Tindouf basin and the southern part of Morocco in the Anti-Atlas basin, with TOC of about $0.2 \%$ at present, which is believed to have been more than it present content due to the high level of maturity (Luning et al. 2009) of this source rock in the area. The source rocks to the Taoudeni basin hydrocarbons according Gang (2009) is varied from Cambrian (Infracambrian) through to Devonian to Silurian but largely of Silurian (Huang et al. 2003), with source rock thickness of minimum $20 \mathrm{~m}$ and maximum in excess of $500 \mathrm{~m}$.

\section{Voltaian basin petroleum prospects}

The Voltaian basin covers most central parts of Ghana (Fig. 2) with a total area of about $115,000 \mathrm{~km}^{2}$ (Affaton et al. 1980; Abu et al. 2019a). The basin has well exposed outcrops with a thick sedimentary succession of about 5-7 $\mathrm{km}$ thick in its depocenter located toward the southeastern parts. The basin (Table 1) is of both chemical sediments (carbonates and cherts) as well as detrital sediments (Anani 1999; Saunders 1970). Although no available drill cores to validate Bozkho (2008) assertion that, the drill holes in an attempt to investigate the hydrodynamics of the Voltaian basin by Soviet Geological Survey Team (SGST) yielded black viscous oily bitumen in these boreholes from sandstones and carbonates, especially at Nasia (764 m), Buipe (450 $\mathrm{m}$ ) and Yendi $(698 \mathrm{~m})$ within the Oti/Pendjari Group

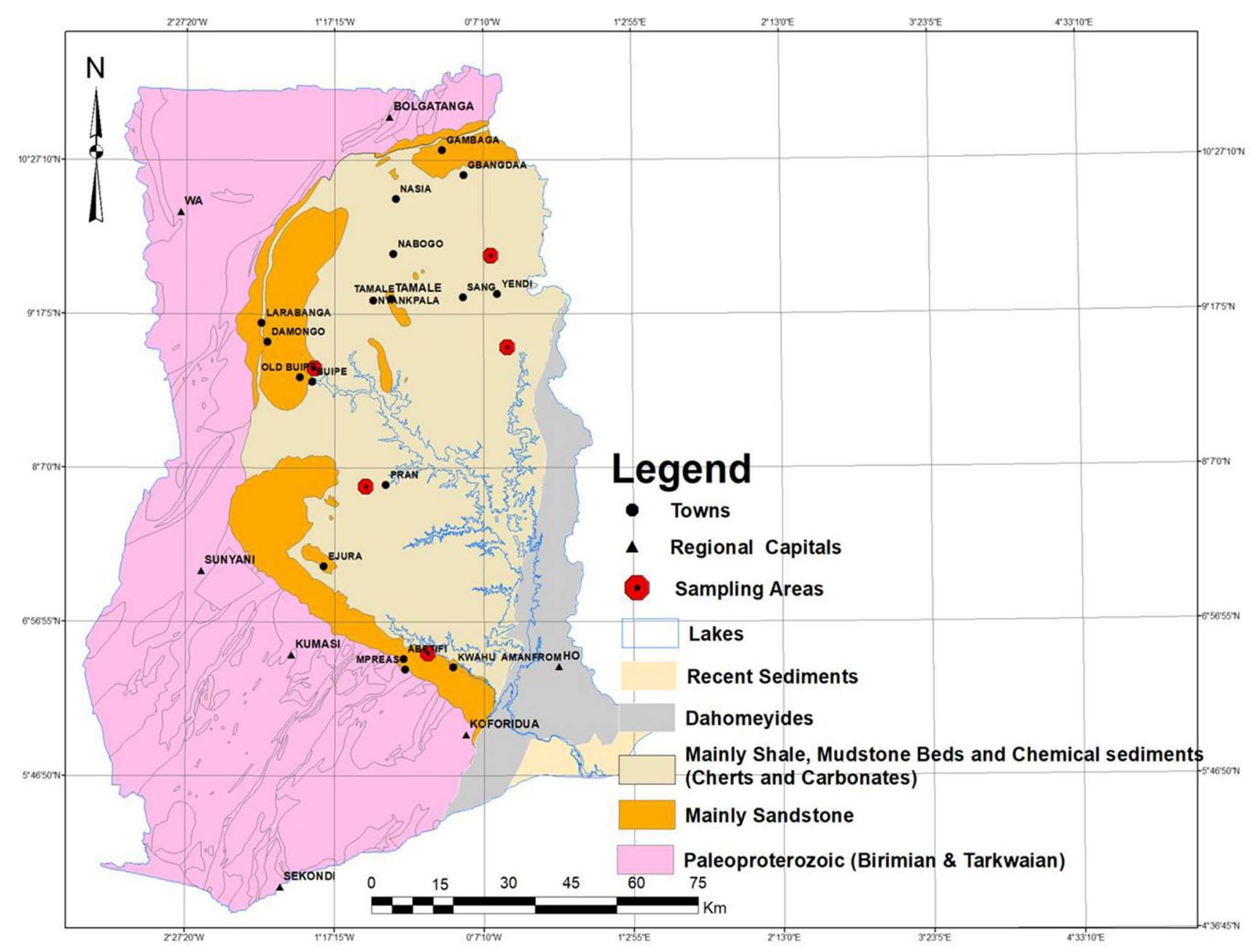

Fig. 2 A simplified Geological map of the Voltaian basin, Ghana with proposed sampling areas for hydrocarbon assessment purposes in perspective 
and Prang $(587 \mathrm{~m})$ close to the top of the lower Kwahu/ Bombouaka Group (Panabako Formation) (Bozkho 2008) at varying depths. Organic petrographical studies indicated the presence of microfossils including Acritarchs, Cambrian Chuaria and Pendjariensis (Amard 1997) observed from sediments belonging to the Oti/Pendjari Group. The carbonates from the Gbandaa-Gbintiri (Fig. 1) areas are largely dolomitic limestones from recently analyzed 12 samples using XRF method at the Geological Survey Authority, Ghana (Abu et al. 2019b). The carbonates in the northeastern region are barite bearing and this is due to hydrothermal mineralization of the carbonates. There is also the presence of bitumen in quartz veins (Fig. 3a) and carbonate rocks at Buipe quarry (Fig. 3b, c) (Boamah 2017).

The argillaceous sediments of the Pendjari Formation of the Oti/Pendjari Group with microfossils (Amard 1992; Amard 1997), suggest their suitability for source rocks to a possibly deeply buried shale gas and/or oil shale in the Voltaian basin. The presence of visible bitumen in the Buipe carbonates observed at the Buipe limestone quarry (Fig. 3) of the Kodjari Formation of the Oti/Pendjari Group, supports the reservoir probability of the dolomitic limestones of the basin although needs to be proven with empirical evidence to support their suitability, from an extensive geological research on the basins hydrocarbon prospectivity.

\section{Conclusions}

The Voltaian basin of Ghana has experienced similar geological events of the Neoproterozoic geological time, particularly during the Cryogenian (Marinoan) which was a global event thus, the great oxidation event (GOE). This global geological event is associated with the deposition of marginal-shallow marine carbonates, dolomitic limestones, dolostones together with argillaceous sediments which are present in the Oti/Pendjari Group of the Voltaian basin. This period favored the preservation of $\mathrm{OM}$ in siliciclastics and in carbonates that is rich enough to be source rocks. The carbonates in some of the basins have significant porosity and permeability to be reservoir rocks. Discoveries in all global oil producing Neoproterozoic basins were possible

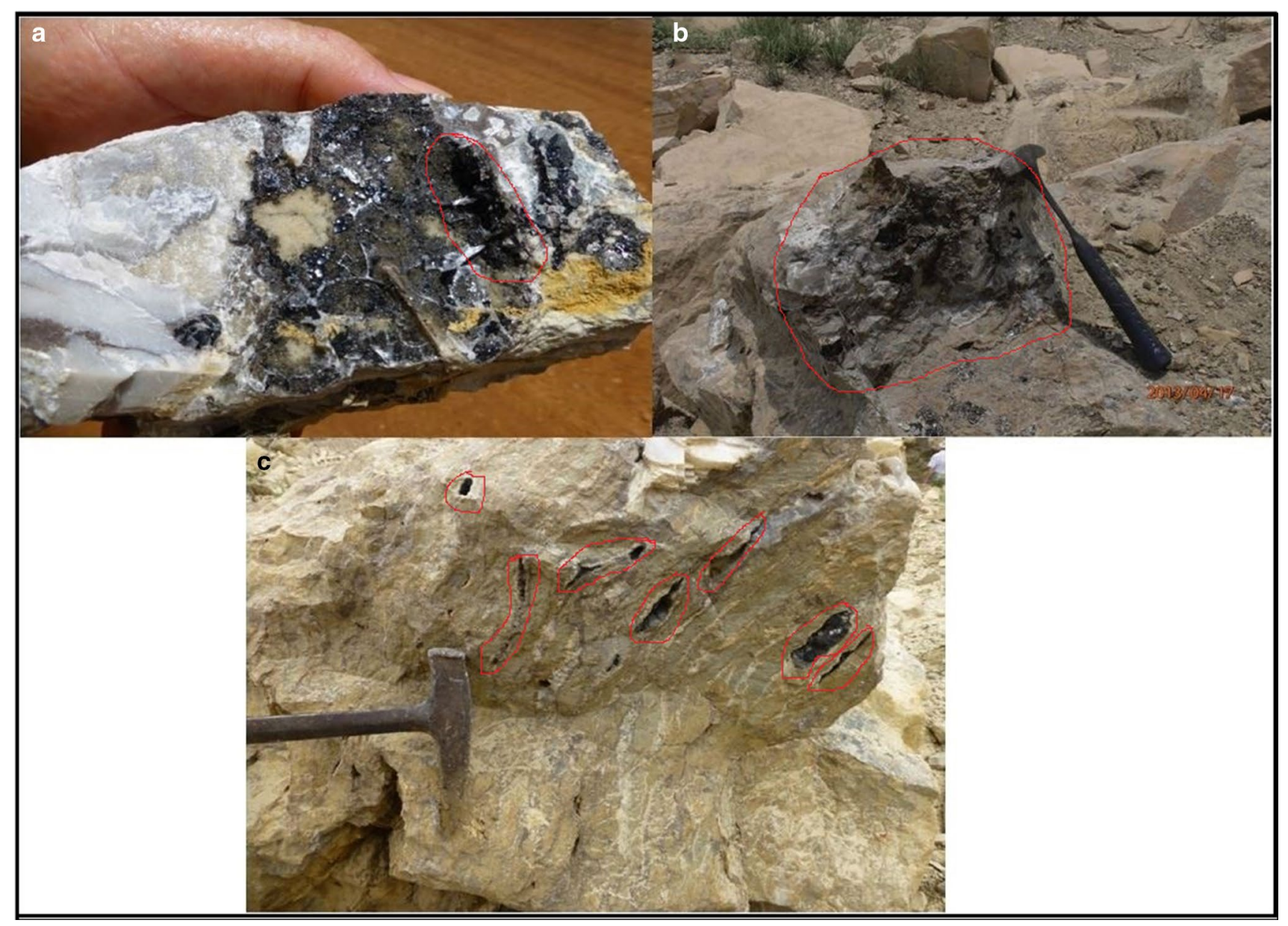

Fig. 3 Bitumen present in quartz veins (a) and within carbonates (b) and as lenses together with quartz veins (c) 
as a result of dedicated and focus exploration efforts in the range of 20-50 years of consistent research and exploration efforts. The adjoining Taoudeni basin to the Voltaian basin has similar geological analogies, with proven and active petroleum system deciphered after long years of consistent research and high risk exploration exercise. The Voltaian basin could be hosting oil/gas like the Taoudeni basin and elsewhere in the Sichuan basin of China.

\section{Recommendation}

The Voltaian basin's hydrocarbon prospectivity is obvious with the presence of bitumen observed in quartz veins and in carbonates, the only problem that is probably stopping or delaying any possible discovery, is the unavailability or lack of resources on the part of the Government to commit into a continuous and consistent research on the basin so as to elucidate its hydrocarbon status. Therefore for any possible discoveries to be made in the basin, which is very possible considering the level of progress and successes chalked by other basins of similar geological events and architecture;

1. The basin, just like all other deeply buried Meso-Neoproterozoic stratigraphic successions mostly in the excess of $5 \mathrm{~km}$, have to be explored having in mind of the expensive nature of hydrocarbon exploration across Neoproterozoic basins and the time involved.

2. To be able to zero in on the possible area(s) to sink a 'wildcat' or test wells within the basin, there is the need to carry out geochemical screening of outcrop samples (due to the unavailability of core samples), from the central thicker parts and also from the middle shale bearing Poubogou Formation of the Kwahu/Bombouaka Group.

3. In collecting outcrop samples considering indications of similar global Neoproterozoic source/reservoir rocks, the shales and carbonates should both be sampled for source rock evaluation, in an attempt to evaluate the basins' hydrocarbon potential.

Acknowledgement The review is part of the first author's PhD research and he is appreciative of Pan African University sponsorship and also the University of Ibadan, Nigeria, especifically the geology department.

Funding The paper benefited from the PhD scholarship of Pan African University to the first author.

Open Access This article is licensed under a Creative Commons Attribution 4.0 International License, which permits use, sharing, adaptation, distribution and reproduction in any medium or format, as long as you give appropriate credit to the original author(s) and the source, provide a link to the Creative Commons licence, and indicate if changes were made. The images or other third party material in this article are included in the article's Creative Commons licence, unless indicated otherwise in a credit line to the material. If material is not included in the article's Creative Commons licence and your intended use is not permitted by statutory regulation or exceeds the permitted use, you will need to obtain permission directly from the copyright holder. To view a copy of this licence, visit http://creativecommons.org/licenses/by/4.0/.

\section{References}

Abu M, Sunkari ED, Sener M (2019a) Untapped economic resource potential of the Neoproterozoic to early Paleozoic Volta Basin, Ghana: a review. Nat Resour Res. https://doi.org/10.1007/s1105 3-019-09478-5

Abu M, Sunkari ED, Philemon SD (2019b) Sedimentology and Geochemistry of carbonate rocks in the Volta Basin and their suitability for industrial purposes. In: Annual conference of the Ghana Institution of geoscientists

Affaton P, Sougy J, Trompette R (1980) The tectono-stratigraphic relationships between the upper Precambrian and lower Paleozoic Volta Basin and the Pan-African Dahomeyideorogenic belt West Africa. Am J of Sci 280:240-248

Akah AK (2008) Geochronology of detrital zircons from Bombouaka Group sandstones in the Gambaga and Kintampo massifs. In: Kalsbeek F (ed) The Voltaian Basin, Ghana. Workshop and Excursion, March 10-17, Abstract Volume. Geological Survey of Denmark and Greenland in Copenhagen, pp 55-56

Albert-Villanueva E, Permanyer A, Tritlla J, Levresse G, Salas R (2016) Solid hydrocarbons in proterozoic dolomites, Taoudeni Basin Mauritania. J Petrol Geol 39(1):5-28

Amard B (1992) Ultrastructure of Chuaria (Walcott) Vidal and Ford (Acritarcha) from the late Proterozoic Pendjari formation, Benin and Burkina-Faso, West Africa. Precambr Res 57:121-133

Amard B (1997) Chuaria pendjariensis n. sp., acritarche du bassin des Volta, Benin et Burkina-Faso, Afrique de 1_Ouest: Un taxon nouveau du Cambrien infe_rieur. Comp Ren Acad Sci Paris 324:477-483

Amthor JE, Ramseyer K, Faulkner T, Lucas P (2005) Stratigraphy and sedimentology of a chert reservoir at the PrecambrianCambrian Boundary: the Al Shomou Silicilyte, South Oman Salt Basin. GeoArabia 10:89-122

Anani CY (1999) Sandstone petrology and provenance of the Neoproterozoic Voltaian Group in the southeastern Voltaian Basin, Ghana. Sed Geol 128:83-98

Anani CY, Mahamuda A, Kwayisi D, Asiedu DK (2017) Provenance of sandstones from the Neoproterozoic Bombouaka Group of the Volta Basin, northeastern Ghana. Arab. J. Geosci. 10:465. https://doi.org/10.1007/s12517-017-3243

Apesigah E (2008) Hydrocarbon potential of the Voltaian Basin (Post-Premuase-1 Well). Workshop and Excursion, Abstract Volume

Bacheller WD, Peterson RM (1991) Hassi Messaoud Field; Algeria, Trias Basin, Eastern Sahara Desert. In: Foster NH, Beaumont EA (eds) AAPG treatise of petroleum geology: atlas of oil and gas fields. American Association of Petroleum Geologists, Tulsa, pp 211-225

Barfod GH, Vervoort JD, Montanez IP, Riebold S (2004) Lu-Hf geochronology of phosphates in ancient sediments. In: 13th Goldschmith Conference, Copenhagen. Geochimica et Cosmochimica Acta, Abstract Volume, vol 68, p A336

Bechstadt T, Ger H, Spence G, Werner G (2009) Late Cryogenian (Neoproterozoic) glacial and post-glacial successions at the southern margin of the Congo Craton, northern Namibia: facies, palaeogeography and hydrocarbon perspective. Geol Soc Lond 326:255-287. https://doi.org/10.1144/SP326.15

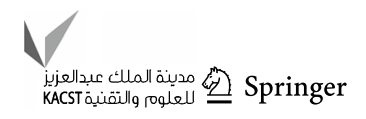


Beghin J, Storme J, Blanpied C, Gueneli N, Brocks JJ, Poulton SW, Javaux EJ (2017) Microfossils from the late Mesoproterozoicearly Neoproterozoic Atar/El Mreïti Group, Taoudeni Basin, Mauritania, northwestern Africa. Precambr Res 268(16):3013330134. https://doi.org/10.1016/j.precamres.2017.01.009

Bertrand-Sarfati J, Moussine-Pouchkine A (1998) Mauritanian microbial build ups; meso-neoproterozoic stromatolites and their environment; six days field trip on the Mauritanian Adrar. Association des Sedimentologistes Francais, Paris, vol 31

Beukes NJ (1986) A field introduction to the geology of the Otavi Mountainland, Northern Namibia. Workshop on Precambrian Carbonate Sedimentology. Tsumeb Corp. Ltd., Tsumeb

Boamah KO (2017) Minerogeny of the Pan-African Volta Basin, Ghana. Ph.D. thesis, TU-Bergakadamie, Freiberg

Bozhko NA, Kazakov GA, Trofimov DM, Knoppe GK, Yu A, Gatinski B (1971) New absolute dating of West-African glauconites. Doklady Akademii Nauk SSSR 214:643-646

Bozhko N (2008) Stratigraphy of the Voltaian basin on evidences derived from borehole loggins. The Voltaian Basin, Ghana Workshop and Excursion, March 10-17

Carney JN, Jordan CJ, Thomas CW (2008) Field excursion guide and notes. In: Kalsbeek F (ed) The Voltaian Basin, Ghana. Workshop and Excursion. Geological Survey of Denmark and Greenland (GEUS), Copenhagen, pp 107-132

Carney JN, Jordan CJ, Thomas CW, Condon DJ, Kemp SJ, Duodo JA (2010) Lithostratigraphy, sedimentation and evolution of the Volta Basin in Ghana. Precambr Res 18:701-724

Clauer N (1976) Géochimie isotopique du Strontium des milieux sedimentaires. Application à la géochronology de la couverture de craton Ouest-africain, vol 45. Mem. Sci. Géol., Strasbourg, p 256

Craig J, Thurow J, Thusu B, Whitham A, Abutarruma Y (2009) Global Neoproterozoic petroleum systems and the emerging potential in North Africa. In: Craig J, Thurow J, Whitham A, Abutarruma Y (eds) Global neoproterozoic petroleum systems: the Emerging Potential in North Africa. Geological Society, London, vol 326, pp 1-24

Craig J, Grigo D, Rebora A, Serafini G, Tebaldi A (2010) From Neoproterozoic to Early Tertiary: exploring the potential of older and deeper hydrocarbon plays across North Africa and the Middle East. In: Vining BA, Pickering SC (eds) Petroleum geology: from mature basins to new frontiers. Proceedings of the 7th petroleum geology conference, vol 7. Petroleum Geology Conference Series, pp 673-705

Craig J, Biffi U, Galimberti RF, Ghori KAR, Gorter JD, Hakhoo N, Heron DP Le Thurowe J, Vecoli M (2012) The palaeobiology and geochemistry of Precambrian hydrocarbon source rocks. Mar Petrol Geol 1-47. https://doi.org/10.1016/j.marpetgeo.2012.09.011

Dardour AM, Boote DRD, Baird AW (2004) Stratigraphic controls on palaeozoic petroleum systems, Ghadames Basin, Libya. J Petrol Geol 27(2):141-162

Energy Information Administration (2015) International energy data and analysis. https://www.eia.gov/beta/international/ (August 28, 2015)

Gang W (2009) Hydrocarbon generation conditions and exploration potential of the Taoudeni Basin, Mauritania. Pet Sci 6:29-37. https://doi.org/10.1007/s12182-009-0006-z

Ghienne JF (2003) Late Ordovician sedimentary environments, glacial cycles, and post-glacial transgression in the Taoudeni Basin, West Africa. Palaeogeogr Palaeoclimatol Palaeoecol 189:117-145

Ghori KAR, Craig J, Thusu B, Luning S, Geiger M (2009) Global Infracambrian petroleum systems. In: Craig J, Thurow J, Thusu B, Whitham A, Abutarruma Y (eds) Global neoproterozoic petroleum systems and the emerging potential in North Africa. Geological Society, London, vol 326, pp 109-136
Goodwin AM (1996) Principles of Precambrian geology. Academic Press, New York

Grant NK (1969) The late Precambrian to early Paleozoic Pan-African orogeny in Ghana, Togo, Dahomey, and Nigeria. Geol Soc Am Bull 80:45-56

Grosjean E, Love GD, Stalvies C, Fike DA, Summons RE (2009) Origin of petroleum in the Neoproterozoic-Cambrian South Oman Salt Basin. Org Geochem 40:87-10

Hackley PC, Fishman N, Wu T, Baugher G (2016) Organic Petrology and Geochemistry of Mudrocks from the Lacustrine Lucaogou Formation, Santanghu Basin, Northwest China: Application to Lake Basin Evolution. Int J Coal Geol. https://authors.elsevier. com/sd/article/S0166516216302257. http://dx.doi.org/https://doi. org/10.1016/j.coal.2016.05.011

Hao S, Liu G (1989) Precambrian oil and gas in China. AAPG Bull $73: 412$

Hirst JPP, Benbakir A, Payne DF, Westlake IR (2002) Tunnel valleys and density flow processes in the upper Ordovician glacial succession, Illizi Basin, Algeria: influence on reservoir quality. J Pet Geol 25:297-324

Hoffman PF, Schrag DP (2002) The snowball earth hypothesis: testing the limits of global change. Terra Nova 14:129-155

Hoffmann KH, Condon DJ, Bowring SA, Crowley JL (2004) U-Pb zircon date from the Neoproterozoic Ghaub Formation, Namibia: Constraints on Marinoan glaciation. Geology 32:817-820

Huang ZL, Zhong NN, Zhang SH (2003) Comparison researches on gas generating rule of carbonate rocks and argillaceous source rocks. Geochimica. 32(1):29-34 (in Chinese)

Jarvie DM (2012) Shale resource systems for oil and gas: Part 1shale-gas resource systems. In: Breyer JA (ed) Shale reservoirsgiant resources for the 21st century. AAPG Memoir 97, pp 69-87

Kelly AE, Love GD, Zumberge JE (2011) Hydrocarbon biomarkers of Neoproterozoic to lower Cambrian oils from eastern Siberia. Org Geochem 42(6):640-654

Kalsbeek F, Frei D, Affaton P (2008) Constraints on provenance, stratigraphic correlation and structural con-text of the Volta Basin, Ghana, from detrital zircon geochronology: an Amazonian connection? J Sediment Geol 212:86-95

Konert G, Afifi AM, Al Hajri SA, Droste HJ (2001) Paleozoic stratigraphy and hydrocarbon habitat of the Arabian Plate. GeoArabia 6:407-442

Laukamp C (2006) Structural and fluid system evolution in the Otavi Mountainland (Namibia) and its significance for the genesis of sulphide and nonsulphide mineralization. $\mathrm{PhD}$ thesis, University of Heidelberg

Le Heron D, Sutcliffe O, Bourgig K, Craig J, Visentin C, Whittington R (2004) Sedimentary architecture of Upper Ordovician tunnel valleys, Gargaf Arch, Libya: Implications for the genesis of a hydrocarbon reservoir. GeoArabia 9:137-160

Le Heron DP, Dowdeswell JA (2009) Calculating ice volumes and ice flux to constrain the dimensions of a 440 Ma North African ice sheet. Journal of the Geological Society, London 166:277-281

Le Heron DP, Craig J, Etienne JL (2009) Ancient glaciations and hydrocarbon accumulations in North Africa and the Middle East. Earth-Sci Rev 93:47-76

Luning S, Kolonic S, Geiger M, Thusu B, Bell JS, Craig J (2009) Infracambrian hydrocarbon source rock potential and petroleum prospectivity of NW Africa

Lottaroli F, Craig J, Thusu B (2009) Neoproterozoic-Early Cambrian (Infracambrian) hydrocarbon prospectivity of North Africa: a synthesis. Geological Society, London, Special Publications 326:137-156

Ma Y, Zhang S, Guo T, Zhu G, Cai X, Li M (2008) Petroleum geology of the Puguang sour gas field in the Sichuan Basin, SW China. Mar Pet Geol 25:357-370 
Mattes BW, Morris SC (1990) Carbonate/evaporite deposition in the Late Precambrian-Early Cambrian Ara Formation of Southern Oman

McKirdy DM, Imbus SW (1992) Precambrian petroleum: a decade of changing perceptions. In: Schidlowski M, Kimberley MM, Golubic S, McKirdy DM, Trudinger PA (eds) Early organic evolution: implications for mineral and energy resources. Springer, Berlin, pp 176-192

Nédélec A, Affaton P, France-Lanord C, Charrière A, Alvaro J (2007) Sedimentology and chemostratigraphy of the Bwipe Neoproterozoic cap dolostones (Ghana, Volta Basin): a record of microbial activity in a peritidal environment. CR Geosci 339:223-239

Saunders SR (1970) Early Paleozoic orogeny in Ghana: foreland stratigraphy and structure. Geol Soc Am Bull 81:233-240

Sieminski A (2016) Energy information administration, monthly energy review. Overview 28

Ulmishek GF (2001) Petroleum geology and resources of the Baykit High Province, East Siberia, Russia. US Geol Surv Bull 2201-F:1-18

Viljeon JHA, Agyapong W, Le Berre W, Reddering JSV, Thomas E, Atta-Ntim K (2008) Geology of sheet 1001D south of Gambaga
Wang M, Zhang GB, Zhu ZG (2005) Assessment of oil and gas resources of China-2005. The Office of National Oil and Gas Resource Assessment, Beijing (in Chinese)

Wang H, Ma F, Tong X, Liu Z, Zhang X, Wu Z, Li D, Wang B, Xie Y, Yang L (2016) Assessment of global unconventional oil and gas resources. Petrol Explor Develop 43(6):925-940

Yin CY, Bengtson S, Yue Z (2004) Silicified and phosphatized Tianzhushania, spheroidal microfossils of possible animal origin from the Neoproterozoic of South China. Acta Palaeontol Pol 49:1-12

Zhang Z, Mahoney JJ, Mao J, Wang F (2006) Geochemistry of Picritic and associated basalt flows of the western emeishan Flood Basalt Province, China. Acta Petrol Sin 22:1997-2019

Zhu GY, Zhang SC, Liang YB, Dai JX (2006) Stable sulfur isotopic composition of hydrogen sulfide and its genesis in Sichuan Basin. Geochimica 35(4):412-422 (in Chinese)

Publisher's Note Springer Nature remains neutral with regard to jurisdictional claims in published maps and institutional affiliations. 